\title{
ImmunoFISH for Adherent Cultured Mammalian Cells
}

Francesca Rossiello, Marzia Fumagalli and Fabrizio d'Adda di Fagagna*

The FIRC Institute for Molecular Oncology, IFOM, Milan, Italy

*For correspondence: fabrizio.dadda@ifom.eu

[Abstract] This protocol is optimized for immunoFISH staining of adherent cultured mammalian cells. It combines immunofluorescence for DNA damage response factors (e.g. 53BP1) and FISH against telomeric DNA.

\section{Materials and Reagents}

1. Cells

2. $4 \%$ PFA

3. Methanol/acetone 1:1

4. TritonX100

5. Primary antibody : 53BP1 \#NB 100-304 rabbit from Novus

6. Second antibody: goat anti-rabbit Alexa Fluor ${ }^{\circledR} 488$ Dye

7. PBS

8. Glycine

9. Fish gelatin (Sigma-Aldrich, catalog number : G7041)

10. $\mathrm{BSA}$

11. Formamide

12. Tris $\mathrm{HCl}, \mathrm{pH} 7.4$

13. Telomeric PNA probe (TelC-Cy3 from PANAGENE, catalog number: F1002-5)

14. DAPI

15. Mowiol 4-88 reagent (Calbiochem ${ }^{\circledR}$ )

16. PBG (see Recipes)

17. Hybridization mixture (see Recipes)

18. Blocking reagent (Roche Diagnostics, catalog number: 11096176001) (see Recipes)

19. Wash solution I (see Recipes)

20. Wash solution II (see Recipes)

\section{Equipment}

1. Glass coverslips 
2. 12 multiwell plate

3. Metal thermoblock

4. Humidified chamber

\section{Procedure}

1. Grow cells on glass coverslips (e.g. BJ normal human fibroblasts).

2. Transfer the coverslip to a 12 multiwell plate.

3. Wash briefly with $1 x$ PBS.

4. Fix with either $4 \%$ PFA, $10 \mathrm{~min}, \mathrm{RT}$ or methanol/acetone 1:1, $2 \mathrm{~min}, \mathrm{RT}$ (it depends on the antibody, does not affect the FISH signal; use methanol/acetone for 53BP1 staining).

5. Wash with 1x PBS, 3 times, 5 min.

6. Only for PFA-fixed cells, incubate with $0.2 \%$ TritonX100 in PBS, $10 \mathrm{~min}$, then wash with $1 \mathrm{x}$ PBS, 3 times, 5 min.

7. Block with $1 \mathrm{x}$ PBG, $1 \mathrm{~h}, \mathrm{RT}$.

8. Incubate with primary antibody diluted in $1 \times \mathrm{PBG}, 50 \mu$ for each coverslip. Incubation time depends on the antibody, most work in $1 \mathrm{~h}, \mathrm{RT}$, or overnight at $4{ }^{\circ} \mathrm{C}$. (For 53BP1 dilute $1: 200$ and incubate $1 \mathrm{~h}$ at $\mathrm{RT}$ ).

9. Wash with $1 \times$ PBG, 3 times, 5 min.

10. Incubate with secondary antibody diluted in 1x PBG, $45 \mathrm{~min}, \mathrm{RT}$.

11. Wash with $1 \times$ PBG, twice, 5 min.

12. Wash with $1 \times$ PBS, twice, 5 min.

13. Re-fix cells with PFA $4 \%$ + triton $0.1 \%, 10$ min RT (use PFA also if you have previously fixed cells with methanol/acetone).

14. Incubate with glycine $10 \mathrm{mM}$ in $\mathrm{H}_{2} \mathrm{O}, 30 \mathrm{~min}, \mathrm{RT}$.

15. Wash with 1x PBS, 3 times, 5 min.

16. Prepare the hybridization mixture and put $20 \mu \mathrm{l}$ on a glass slide for each coverslip.

17. Transfer the coverslip carefully on the drop without making bubbles.

18. Put the slide directly on a metal thermo block at $80^{\circ} \mathrm{C}, 5 \mathrm{~min}$.

19. Hybridize in a humidified chamber, $2 \mathrm{~h}, \mathrm{RT}$.

20. Remove coverslip from the slide and put it back in the 12 wells plate.

21. Wash with Wash solution I, twice, $15 \mathrm{~min}$.

22. Wash with Wash solution II, 3 times, $5 \mathrm{~min}$.

23. Incubate with DAPI, 2 min, RT.

24. Wash briefly with $1 x$ PBS.

25. Mount with mowiol. 
26. Store the slides at $4{ }^{\circ} \mathrm{C}$ for short time storage ( 2 weeks) or at $-20^{\circ} \mathrm{C}$. It is recommended to analyze the fluorescence as soon as possible to avoid fluorophore fading.

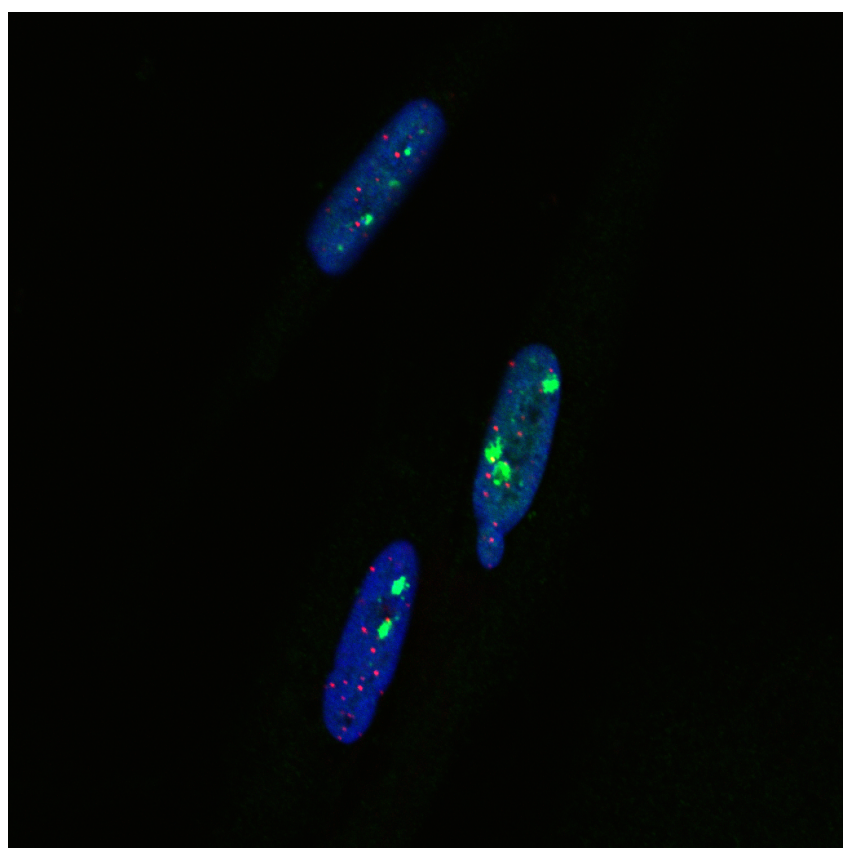

Figure 1. An image of ImmunoFish stained human fibroblasts cells. DAPI is in blue, $53 \mathrm{BP} 1$ is in green and telomeric PNA probe is in red.

\section{$\underline{\text { Recipes }}$}

1. 10x PBG (prepare $5 \mathrm{ml}$ aliquotes and store them in $50 \mathrm{ml}$ tubes at $-20{ }^{\circ} \mathrm{C}$, the day of immunoFISH dilute them in 1x PBS)

$\begin{array}{ll}\text { Fish gelatin } & 2 \% \\ \text { BSA } & 5 \% \\ 1 \times \text { PBS } & \text { to volume }\end{array}$

2. Hybridization mixture (always prepare fresh)

$\begin{array}{ll}\text { Formamide } & 70 \% \\ \text { Blocking reagent } & 1 \mathrm{x} \\ \text { Tris } \mathrm{HCl} \mathrm{pH} 7.4 & 10 \mathrm{mM} \\ \text { Telomeric PNA probe } & 0.5 \mu \mathrm{M} \\ \mathrm{H}_{2} \mathrm{O} & \text { to volume }\end{array}$

3. 10x Blocking reagent

Prepare small aliquots and store them at $-20^{\circ} \mathrm{C}$

4. Wash Solution I $(250 \mathrm{ml})$ (always prepare fresh)

Formamide $\quad 175 \mathrm{ml}$ 
BSA $10 \% \quad 2.5 \mathrm{ml}$

Tris $\mathrm{HCl} 1 \mathrm{M} \mathrm{pH} 7.4 \quad 2.5 \mathrm{ml}$

$\mathrm{H}_{2} \mathrm{O}$ to volume

5. Wash Solution II $(350 \mathrm{ml})$ (always prepare fresh)

Tris $\mathrm{HCl} 1 \mathrm{M} \mathrm{pH} 7.4 \quad 35 \mathrm{ml}$

$\mathrm{NaCl} 5 \mathrm{M} \quad 10.5 \mathrm{ml}$

Tween $2010 \% \quad 2.5 \mathrm{ml}$

$\mathrm{H}_{2} \mathrm{O}$ to volume

\section{Acknowledgments}

The F.d'A.d.F. laboratory is supported by FIRC (Fondazione Italiana per la Ricerca sul Cancro), AIRC (Associazione Italiana per la Ricerca sul Cancro), European Union (GENINCA, contract number 202230), HFSP (Human Frontier Science Program), AICR (Association for International Cancer Research), EMBO Young Investigator Program and Telethon.

\section{References}

1. Fumagalli, M., Rossiello, F., Clerici, M., Barozzi, S., Cittaro, D., Kaplunov, J. M., Bucci, G., Dobreva, M., Matti, V. and Beausejour, C. M. (2012). Telomeric DNA damage is irreparable and causes persistent DNA-damage-response activation. Nat Cell Biol14(4): 355-365. 